\title{
Investigation of a cluster of children with Down's syndrome born to mothers who had attended a school in Dundalk, Ireland
}

\author{
G Dean, N C Nevin, M Mikkelsen, G Karadima, M B Petersen, M Kelly, J O’Sullivan
}

Medico-Social

Research Board (now The Health Research Board), 73 Lower Baggot Street, Dublin 2, Ireland

G Dean (emeritus)

Department of Medical Genetics, The Queen's University of Belfast, Belfast City Hospital, Lisburn Road, Belfast, BT9 $7 \mathrm{AB}$, Northern Ireland, UK N C Nevin

John F Kennedy Institute, G1 Landevej 7, DK-2600, Glostrup, Denmark

M Mikkelsen

M B Petersen

Department of Genetics, Institute of Child Health, Athens, Greece

G Karadima

M B Petersen

Bawnmore, Limerick, Ireland, and St John of God's, Drumcar, County Louth, Ireland M Kelly

Our Lady of Lourdes' Hospital, Drogheda, County Louth, Ireland J O'Sullivan

Correspondence to: Dr G Dean

hrb@hrb.il

Accepted 25 July 2000

\begin{abstract}
Objectives-To investigate a reported cluster of Down's syndrome in offspring of former pupils of a girls' school in Ireland, to establish the prevalence of Down's syndrome among live births in the area around the school, and to review the literature on the possible causes of reported clusters of Down's syndrome.

Methods-Questionnaire survey of obstetric and personal histories of women who had attended the girls' school at Dundalk, County Louth, Republic of Ireland, at some time during 1956-7, and also of women who had attended another, nearby, girls' school during the same period. Comparison of observed numbers of cases of Down's syndrome identified by these surveys with maternal age adjusted expected numbers for the reported live births. Laboratory tests were conducted to verify and characterise the cases of Down's syndrome constituting the cluster. Retrospective collection and collation of data on Down's syndrome occurring among live births, and the compilation of maternal age specific incidences, in County Louth and in Newry and Mourne District in neighbouring Northern Ireland, during 1961-80. These rates were compared with reference rates and rates for other areas of Ireland.
\end{abstract}

Results-Six children with Down's syndrome were confirmed among 387 reported live births to women who had been pupils at the girls' school in Dundalk during 1956-7, compared with 0.69 expected (nominal $\left.\mathrm{p}<10^{-4}\right)$. Five of the affected births were to mothers under 30 years of age, against 0.15 expected (nominal $\mathrm{p}<10^{-6}$ ), although only four of these mothers were attending the school at any one time. The origin of the non-disjunction was found to be maternal first meiotic in four children, mitotic after fertilisation in another (with the youngest mother), and in the remaining one could not be determined. The marked excess of Down's syndrome in births to young mothers did not extend to offspring of former pupils of the other Dundalk girls' school surveyed, or to live births in County Louth generally or in adjacent Newry and Mourne District.

Conclusion-A striking, highly localised, excess of Down's syndrome in births to young mothers who had attended a girls' school in Dundalk during 1956-57 has been confirmed. However, not all of the mothers of the affected children attended the school concurrently and the origin of non-disjunction in one child was an error occurring after conception. Some exposure essentially confined to girls attending the school at this time is a possible, although unlikely, explanation, but a review of potential risk factors does not suggest what this could be. Previous suggestions that an influenza epidemic or contamination from the Windscale nuclear reactor fire might be implicated, both of which occurred in October 1957, can be effectively dismissed because three of the women with affected offspring had left the school by then and had moved away from Dundalk, and Down's syndrome in the child of another mother originated in an error after fertilisation. Owing to the retrospective nature of the investigation and the characteristics of the cases, chance is the most likely explanation for the cluster.

(Occup Environ Med 2000;57:793-804)

Keywords: Down's syndrome; cluster; maternal exposure

In 1983, Sheehan and Hillary ${ }^{1}$ reported the preliminary findings of an investigation into an unusual space-time cluster of six cases of Down's syndrome associated with a small girls' school in the town of Dundalk, County Louth, in the northeast of the Republic of Ireland. The cluster was characterised by births to young mothers who had attended the school during the 1950s and the authors proposed that some exposure of the mothers while pupils at the school could be responsible for this unusual aggregation of births with Down's syndrome. In subsequent correspondence, Sheehan and Hillary $^{2}$ reported that they had learnt of a further two babies with Down's syndrome born to these mothers, bringing the number of cases constituting the cluster to eight, which compares with an estimate of less than one expected. ${ }^{3}$

Sheehan and Hillary ${ }^{1}$ suggested that an outbreak of illness similar to influenza that occurred at the school in October 1957 might be relevant. However, the testing of serum samples from the mothers of the original six affected children, from former pupils of this and two other schools and from similarly aged mothers of children with Down's syndrome in Ireland, for antibodies to several strains of influenza and other infectious agents, showed nothing unusual. ${ }^{1}$ The authors further sug- 
gested $^{1}$ that radioactive contamination from the fire (the Windscale fire) in October 1957 at the Windscale No 1 Pile, a nuclear reactor at Sellafield in northwest England, could be a possible factor. In subsequent correspondence $^{3}{ }^{4}$ it was pointed out that fallout from this fire did not make a significant contribution to the radiation exposure of the population of either Dundalk in particular or Ireland in general, and that evidence that exposure to ionising radiation increases the risk of Down's syndrome in offspring is weak. However, Sharp and $\mathrm{McConnell}^{3}$ concluded that the cluster was a sufficiently unusual occurrence that alternative explanations should be examined. The existence of the cluster has been widely reported in the media.

Sheehan continued her investigation of this cluster, but did not publish any further findings in the scientific literature before her death in 1994. One of us (GD) has been given access to Sheehan's papers so that additional data from her study of the cluster could be collated and analysed. Also, data on the incidence of Down's syndrome in Dundalk and its general vicinity have been collected to assess whether the cluster is part of a broader phenomenon. In this paper we report the results of this work. We also review the literature on what is known of the causes of Down's syndrome.

\section{Methods}

QUESTIONNAIRE SURVEY

A remark in 1974 by the mother of a child with Down's syndrome about the number of her schoolfriends with similarly affected children led Sheehan to contact women whom she had identified as attending St Louis' Secondary School for Girls in Dundalk at some time between September 1951 and June 1961. ${ }^{12}$ St Louis' School was a small convent secondary school situated on the outskirts of Dundalk, attended by girls aged 11-18 years, which opened for day pupils in 1950 and for boarders in 1953. After the publication of the preliminary findings about the cluster, in 1987 Sheehan issued a questionnaire, enquiring about obstetric and personal histories, to 178 women whom she had identified from school examination rolls and dates of birth as attending St Louis' School during the years 1956 and 1957. Presumably, this period was chosen because the cases of Down's syndrome had been found from her initial enquiries to be concentrated among births to mothers who had attended the school at some time in these 2 years. A questionnaire was also sent by $\mathrm{Dr}$ Sheehan to each of the 671 women whom she had similarly identified as attending a day school for girls aged 5-18 years in Dundalk (St Vincent's School, the largest girls' school in the town) during 1956-7. The questionnaire phase of the study was closed at the end of 1988 and no results have been reported in the scientific literature.

LABORATORY TESTS

Owing to the potential importance of the cluster of eight births with Down's syndrome reported to be associated with St Louis'
School, checks were made on the identification and diagnosis of these children, and on information about maternal attendance at the school during the 1950s. One of us (GD), with the cooperation of St Louis' School, checked the details of the mothers contained in Sheehan's documents against school records. Another of us (MM) had collaborated with Sheehan in a cytogenetic analysis of peripheral blood lymphocytes sampled from the five affected children who were alive in 1984 to confirm Down's syndrome. (One of these five died at the age of 19 years in 1985.) Blood had also been sampled from the parents, so that chromosomal fluorescence heteromorphisms (method described by Mikkelsen et $a l^{5}$ ) could be used to find the origin of the supernumerary chromosome 21 and the meiotic stage of gametogenesis of the non-disjunction that led to trisomy in the child. The results of this cytogenetic analysis have not been previously reported. More recently, the four surviving children and their parents have provided further biological samples, in all but one instance blood, the exception being a buccal smear from one of the fathers. Also, an infant who was subsequently reported ${ }^{2}$ as affected with Down's syndrome and who died at the age of 8 weeks had had a necropsy, and blocks had been kept; we were given access to this material, and the parents provided blood samples. Thus, biological material was available from five affected people and their parents for analysis for DNA polymorphisms to find the parental origin of the non-disjunction. Microsatellite DNA polymorphisms spanning the entire 21q were detected after polymerase chain reaction (PCR) amplification of genomic DNA. ${ }^{6}$ The 12 polymorphisms studied were the short sequence repeats at loci D21S369, D21S215, D21S258, D21S16, D21S11, D21S214, D21S210, D21S213, HMG14, D21S212, D21S171, D21S1575. Amplification of the PCR with end labelling of primers, polyacrylamide gel electrophoresis of the amplification products, and autoradiography were performed as described by Petersen et al. ${ }^{7}$ All loci have been localised on the genetic linkage map of human chromosome $21 .^{8}$ The parental origin of the extra chromosome 21 was found by dose analysis when two different alleles were present in the proband, or by scoring the polymorphic alleles when three different alleles were present. ${ }^{9}$ The meiotic stage of nondisjunction (meiosis i or ii) was assigned on the basis of reduction to homozygosity at the four pericentromeric $21 \mathrm{q}$ loci. ${ }^{10} \mathrm{~A}$ mitotic error after fertilisation was assumed when pericentromeric markers were reduced to homozygosity and there was lack of recombination along the entire $21 \mathrm{q} .{ }^{11}$

DOWN'S SYNDROME IN COUNTY LOUTH

County Louth (population 67378 at the 1961 census) has two main towns, Dundalk (1961 population 19790 ) in the north of the county and Drogheda (1961 population 17 085) in the south (figure). Louth County Hospital is located in Dundalk and Our Lady of Lourdes' Hospital in Drogheda. One of us (JO'S) was a 


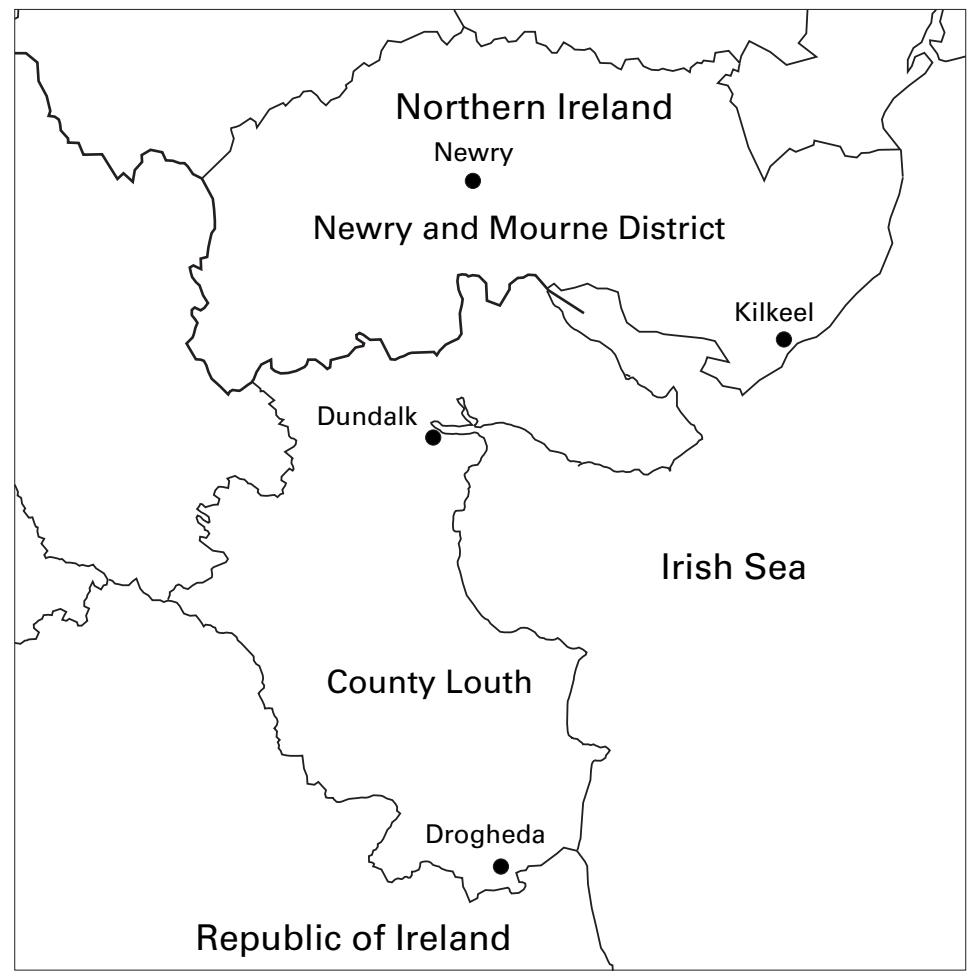

Map showing County Louth, Republic of Ireland, and Newry and Mourne District, Northern Ireland, and the location of the major towns in these two areas.

paediatrician at Our Lady of Lourdes' Hospital where most babies with Down's syndrome born to mothers resident in County Louth would have been examined, as until recently there was no paediatrician at Louth County Hospital. Down's syndrome among live births between 1961 and 1980 to mothers who were normally resident in County Louth was of specific interest because of the possibility of some exposure of the mothers, as schoolgirls, in 1956-7. These cases were identified from several sources: the register of the handicapped; hospital records in Dundalk and Drogheda, in Newry and Kilkeel in adjacent Northern Ireland, and in Dublin; and, since people with Down's syndrome could have died in infancy, death registers. Other sources of information were a major centre for the care of the mentally handicapped, St John of God's, at Drumcar, County Louth (where one of us (MK) was based); the Foundation for the Prevention of Childhood Handicap; the Down's Syndrome Association of Ireland; and the records of the cytogenetics laboratories at University College Dublin and University College Galway. For the mothers of affected children, maiden names were obtained from hospital and birth registers and ages at birth from hospital records, and this information was compared with details of girls who had attended St Louis' School or St Vincent's School. The maternal age profile of all live births to women resident in County Louth during 1961-80 is available for each year from the Central Statistics Office, but birth data were not routinely collated for smaller geographical units within County Louth. There is no prenatal testing for Down's syndrome in the Republic of Ireland, and so induced abortion does not influence the prevalence of Down's syndrome among live births.

DOWN'S SYNDROME IN NEWRY AND MOURNE DISTRICT

Owing to the closeness of Dundalk to Northern Ireland, data on incidence of Down's syndrome for the district of Northern Ireland adjacent to County Louth, Newry and Mourne District (figure), were also collected and collated for the period 1961-80. Newry and Mourne District was created in 1974 from six local authority areas and the population of the district at the 1981 census was 79205 . The main town, Newry (1981 population 20 554), contains the principal hospital serving the district (Daisy Hill Hospital) and a small private hospital, and a small hospital is also located at Kilkeel. Another hospital in Newry (Newry General Hospital) closed in 1975 and many of the medical records were destroyed. A register of congenital abnormalities among births to women resident in Northern Ireland has been maintained in Belfast by one of us (NN) since $1970 .^{12}$ Down's syndrome in births to women normally resident in Newry and Mourne District were identified from this register. Down's syndrome in births in this district before 1970 were identified from hospital records, registers of deaths, records of the handicapped, and those of the Down's Syndrome Association of Northern Ireland, records of the cytogenetics laboratory in Belfast, a survey of Down's syndrome in Northern Ireland carried out by the Institute for Counselling and Personal Development, and general practitioners. As the congenital abnormalities register in Belfast may not have been complete in the early years of its existence these sources of information were also used to cross check against the registry data for the period from 1970. Prenatal diagnosis and subsequent induced abortion is practised in Northern Ireland and account must be taken of such cases to allow a proper comparison with prevalences of Down's syndrome among live births in the Republic of Ireland. Therefore, records at Belfast were checked by one of us (NN) to identify any such instances among women living in Newry and Mourne District. As for County Louth, maiden names and ages at birth of mothers of children with Down's syndrome from Newry and Mourne District were obtained from birth and hospital registers. This information was checked against the school roll of St Louis' School.

The maternal age structure of all live births to mothers resident in Newry and Mourne District is readily available for 1974 onwards from computerised records held by the Registrar General's Office, but no easily accessible source of such information exists for the years before 1974. As a consequence, records for all live births in three hospitals in Newry and Mourne District during the years 1961, 1966, and 1970 were examined to obtain maternal ages. It was assumed that the annual proportions of these births by maternal age group varied linearly between the years sampled. These annual proportions were then applied to 
Table 1 Details of Down's syndrome births to mothers who had attended St Louis'Secondary School, Dundalk, during 1956-7, as obtained from completed questionnaires

\begin{tabular}{|c|c|c|c|c|c|c|c|c|}
\hline $\begin{array}{l}\text { Case } \\
\text { identifiert }\end{array}$ & $\operatorname{Sex}$ & $\begin{array}{l}\text { Date of birth } \\
\text { (month/y) }\end{array}$ & Place of birth & Parity & $\begin{array}{l}\text { Maternal } \\
\text { age }(y)\end{array}$ & $\begin{array}{l}\text { Paternal } \\
\text { age }(y)\end{array}$ & $\begin{array}{l}\text { Period at St } \\
\text { Louis' Secondary } \\
\text { School (month/y) }\end{array}$ & Comment \\
\hline 1 & $\mathrm{~F}$ & $6 / 63$ & $\begin{array}{l}\text { Newtownards, Northern } \\
\text { Ireland }\end{array}$ & 1 & 21 & 27 & $9 / 54-6 / 59$ & Boarder \\
\hline 2 & $\mathrm{M}$ & $10 / 64$ & New York & 1 & 26 & 33 & $9 / 54-6 / 56$ & Boarder \\
\hline $3^{\star}$ & $M$ & $5 / 65$ & Drogheda & 1 & 26 & 35 & $9 / 52-6 / 57$ & $\begin{array}{l}\text { Day girl } \\
\text { Child died aged } 8 \text { weeks (necropsy carried out). }\end{array}$ \\
\hline 4 & $\mathrm{~F}$ & $3 / 66$ & Dublin & 1 & 26 & 27 & $9 / 52-6 / 57$ & $\begin{array}{l}\text { Day girl } \\
\text { Child died aged } 19 \text { years (no necropsy). }\end{array}$ \\
\hline 5 & M & $5 / 70$ & Dublin & 1 & 26 & 25 & $9 / 56-6 / 62$ & Boarder \\
\hline 6 & $\mathrm{M}$ & $12 / 72$ & Drogheda & 3 & 31 & 34 & $9 / 55-6 / 59$ & Boarder \\
\hline
\end{tabular}

${ }^{\star}$ Not in original report, ${ }^{1}$ but identified subsequently. ${ }^{2}$

†Not included in this table are one child with Down syndrome who was included in the original report ${ }^{1}$ but whose mother was found not to have attended St Louis' Secondary School, and one child subsequently reported ${ }^{2}$ as affected with Down syndrome who was found not to be so affected (see text).

the annual total number of live births in the District for each year during 1961-70, the annual numbers of live births being estimated from those for the constituent local authority areas on advice from the Registrar General's Office. The maternal age distribution for 1970 and that for 1974 were used to similarly obtain, through linear interpolation of proportions of births by age group, the annual maternal age structure of all live births during 1971-3. Together with the exact number of births in each maternal age group for 1974-80, this procedure allowed the maternal age distribution for all live births during 1961-80 in Newry and Mourne District to be estimated.

ANALYSIS

Observed numbers of cases of Down's syndrome were compared with maternal age adjusted expected numbers. These expected numbers are the sum of maternal age specific expected numbers, generated from the maternal age specific reference rates for the prevalence of Down's syndrome among live births presented by Cuckle et al. ${ }^{13}$ The significance of any excess of observed over expected numbers was found from the Poisson distribution. Significance values relating to the previously reported cluster are nominal because comparisons were not identified initially.

\section{Results}

QUESTIONNAIRE SURVEY

Of the 178 questionnaires issued by Sheehan to women who had been pupils at St Louis' School, Dundalk, during the years 1956 and 1957, 159 (89\%) were completed and returned. Among the 387 live births identified in these questionnaires were five with Down's syndrome included in the original report of Sheehan and Hillary ${ }^{1}$; but the mother of the sixth child with Down's syndrome presented in this original report ${ }^{1}$ was found not to have attended St Louis' School. She was a pupil at a primary day school, Scoil Muire gan Smál (School of the Immaculate Conception), which was under the aegis of the St Louis' Order and was situated about $1 \mathrm{~km}$ away from the secondary school. Questionnaires had not been sent to mothers who had been pupils at this primary school unless they had also attended St Louis' School during 1956-7. Consequently, this sixth child with Down's syndrome should not be included in the cohort of children identified through the questionnaires sent to the specific group of past pupils of St Louis' School.

Two further cases of Down's syndrome were reported ${ }^{2}$ to have occurred among the offspring of former pupils of St Louis' School. Both of these children were reported ${ }^{2}$ to have died. A completed questionnaire was obtained for the mother of one of these children who had been diagnosed with Down's syndrome and had died in infancy. On investigation, the other child was found not to have died and not to have Down's syndrome. This child may have been confused with a relative with Down's syndrome born about the same time.

Details of the six cases of Down's syndrome, identified by the questionnaires as occurring among children whose mothers attended St Louis' School during 1956-7, are given in table 1. The affected children were born between 1963 and 1972, and the births showed no tendency to occur at any particular time or place (table 1). The maternal age at birth was under 30 years in all but one instance, the exception being a mother who was 31 years of age at the time of the birth. Four of the mothers were boarders and two were day pupils at St Louis' School, which is not especially unusual since between $35 \%$ and $40 \%$ of girls attending this school during the 1950 s were boarders.

\section{LABORATORY TESTS}

Five of the affected children and their parents had previously been karyotyped by one of us $(\mathrm{MM})$, and the results are presented in table 2. Primary trisomy 21 was found in all five cases. Samples from four of these five families were available for DNA analysis together with a further family not previously studied, where the child had died shortly after birth and necropsy material was obtained. The conclusions on the origin of the non-disjunction derived from the laboratory analyses are presented in table 2 . (Full details of the DNA polymorphism results, obtained as described in the methods section, can be obtained from one of us (MBP).) Four of the six cases were the result of an error in the first maternal meiotic division. In a further case, chromosome analysis of cytogenetic heteromorphisms had originally assigned the error to the second maternal meiotic division, but DNA analysis showed a mitotic event after fertilisation involving the maternally derived chromosome. The study of cytogenetic 
Table 2 Details of karyotypes and origin of non-disjunction in families of Down's syndrome births to mothers who had attended St Louis' Secondary School, Dundalk, during 1956-7

\begin{tabular}{|c|c|c|c|c|}
\hline \multirow{2}{*}{$\begin{array}{l}\text { Case } \\
\text { identifier }\end{array}$} & \multirow{2}{*}{$\begin{array}{l}\text { Family } \\
\text { Member }\end{array}$} & \multirow[b]{2}{*}{ Karyotype } & \multicolumn{2}{|l|}{ Origin of non-disjunction } \\
\hline & & & Chromosome polymorphisms & DNA polymorphisms \\
\hline \multirow[t]{3}{*}{1} & Father & $46, \mathrm{XY}$ & & \\
\hline & Child & $47, \mathrm{XX},+21$ & Maternal second meiotic & Mitotic after fertilisation \\
\hline & Mother & $46, \mathrm{XX}$ & & \\
\hline \multirow[t]{3}{*}{2} & Father & $46, \mathrm{XY}$ & & \\
\hline & Child & $47, \mathrm{XY},+21$ & Maternal first meiotic & Maternal first meiotic \\
\hline & Mother & $46, \mathrm{XX}$ & & \\
\hline \multirow[t]{3}{*}{$3^{\star}$} & Father & $46, \mathrm{XY}, \operatorname{var}(4)(\mathrm{p} 11, \mathrm{QFQ} 35)$ & & \\
\hline & Child & - & Not studied (child died) & Failed \\
\hline & Mother & $46, \mathrm{XX}$ & & \\
\hline \multirow[t]{3}{*}{4} & Father & $46, X Y$ & & \\
\hline & Child & $47, \mathrm{XX},+21$ & Maternal first meiotic & Not studied (child died) \\
\hline & Mother & $46, \mathrm{XX}$ & & \\
\hline \multirow[t]{3}{*}{5} & Father & $46, \mathrm{XY}$ & & \\
\hline & Child & $47, \mathrm{XX},+21$ & Maternal first meiotic & Maternal first meiotic \\
\hline & Mother & $46, \mathrm{XX}$ & & \\
\hline \multirow[t]{3}{*}{6} & Father & $46, \mathrm{XY}$ & & \\
\hline & Child & $47, \mathrm{XY},+21$ & Maternal first meiotic & Maternal first meiotic \\
\hline & Mother & $46, \mathrm{XX}$ & & \\
\hline
\end{tabular}

^Necropsy carried out at Our Lady of Lourdes' Hospital, Drogheda. Necropsy report gives the underlying cause of death as "mongolism”. Necropsy material unsuitable for DNA analysis.

polymorphisms cannot distinguish between these two mechanisms. It was not possible to find the origin of the non-disjunction in the remaining subject, because of failure of the DNA analysis of the necropsy material, despite several attempts by us and the Forensic Science Service in Birmingham. (The necropsy report for this infant gave mongolism as the underlying cause of death.) Cytogenetic analysis of blood samples taken from the parents of this child, undertaken to exclude the possibility of familial translocation, showed a variant chromosome 4 in the father (table 2). The variant chromosome number 4, identified with QFQbanding, is generally considered to be clinically unimportant.

\section{ANALYSIS}

The maternal age distribution of the 374 live births with the maternal age identified in the returned questionnaires completed by past pupils of St Louis' School is given in table 3. Also given in table 3 are, for each maternal age group, the observed number of births with Down's syndrome and the expected number of such births obtained from maternal age specific reference rates. ${ }^{13}$ The six observed births with Down's syndrome compare with a maternal age adjusted expected number of 0.69 (nominal Poisson $\left.\mathrm{p}(\mathrm{O} \geqslant 6)<10^{-4}\right)$. The five affected births to mothers under 30 years of age compare with 0.15 expected (nominal $\mathrm{p}<10^{-6}$ ).

Table 3 Number of live births, and the number of cases of Down's syndrome observed and expected among these births, by maternal age group, for women who attended St Louis' Secondary School, Dundalk, during 1956-7, as determined by completed questionnaires (reference rates are those obtained by Cuckle et al ${ }^{13}$ )

\begin{tabular}{lclll}
\hline $\begin{array}{l}\text { Maternal age } \\
\text { group }(y)\end{array}$ & $\begin{array}{l}\text { Live births } \\
(n)\end{array}$ & $\begin{array}{l}\text { Observed cases of } \\
\text { Down's syndrome } \\
(n)\end{array}$ & $\begin{array}{l}\text { Reference incidence of } \\
\text { Down's syndrome } \\
\text { (per 10 }\end{array}$ & $\begin{array}{l}\text { Expected cases of } \\
\text { Down's syndrome } \\
(n)\end{array}$ \\
\hline$<20$ & 0 & 0 & 6.2 & 0 \\
$20-24$ & 23 & 1 & 6.7 & 0.015 \\
$25-29$ & 158 & 4 & 8.8 & 0.139 \\
$30-34$ & 127 & 1 & 13.8 & 0.175 \\
$35-39$ & 56 & 0 & 39.3 & 0.223 \\
$40-44$ & 10 & 0 & 138.2 & 0.138 \\
$\geqslant 45$ & 0 & 0 & 404.2 & - \\
N/A $^{\star}$ & 13 & 0 & - & - \\
\hline
\end{tabular}

^Maternal age at the birth not available.
Of the 671 questionnaires issued by Sheehan to women who had been pupils at the larger day school, St Vincent's School, Dundalk, during 1956-7, only 319 (48\%) were completed and returned. Among the 920 live births reported in these completed questionnaires were four children with Down's syndrome, which is in excess of the maternal age adjusted expected number of 1.8 , but not significantly so. Only one of the affected births was to a mother under 30 years of age (she was 29 years of age) which compares with 0.4 expected. Again, this difference is not significant. The results of these comparisons must be viewed with caution given the low response rate.

\section{COUNTY LOUTH AND NEWRY AND MOURNE} DISTRICT

During 1961-70, in 17012 live births to mothers normally resident in County Louth there were 48 babies with Down's syndrome, and during 1971-80 there were 37 with Down's syndrome among 19489 live births. The numbers of these births by maternal age group are given in table 4 , as are the maternal age specific incidences for Down's syndrome in County Louth. Observed numbers did not differ significantly from maternal age adjusted expected numbers for all maternal ages or maternal ages less than 30 years during 1961$70,1971-80$, or 1961-80.

During 1961-70, there were an estimated 17141 live births to mothers resident in Newry and Mourne District, Northern Ireland. Among these births were 37 babies with Down's syndrome. During 1971-80, there were 33 births with Down's syndrome among an estimated number of 16382 live births. No terminations of pregnancy after positive prenatal testing occurred among women resident in Newry and Mourne District during these two periods. From hospital records, maternal ages for live births during 1961, 1966, and 1970 were available for, respectively, $54 \%, 63 \%$, and $86 \%$ of all live births in the District. Details by maternal age group are presented in table 4, where estimated maternal age specific rates are 
Table 4 The numbers of live births, numbers of live births with Down's syndrome and prevalences of Down's syndrome per $10^{4}$ live births, during 1961-80 and 1971-80 by maternal age group for County Louth and Newry and Mourne District (reference incidences of Down's syndrome from Cuckle et al ${ }^{13}$ )

\begin{tabular}{|c|c|c|c|c|c|c|c|}
\hline \multirow[b]{2}{*}{$\begin{array}{l}\text { Maternal age } \\
\text { group }(y)\end{array}$} & \multirow[b]{2}{*}{$\begin{array}{l}\text { Reference } \\
\text { incidence of } \\
\text { live births } \\
\text { with Down's } \\
\text { syndrome } \\
\left(\times 10^{-4}\right)\end{array}$} & \multicolumn{3}{|l|}{$1961-70$} & \multicolumn{3}{|l|}{$1971-80$} \\
\hline & & $\begin{array}{l}\text { Live births } \\
\text { (n) }\end{array}$ & $\begin{array}{l}\text { Live births } \\
\text { with Down's } \\
\text { syndrome (n) }\end{array}$ & $\begin{array}{l}\text { Prevalence of } \\
\text { live births with } \\
\text { Down's } \\
\text { syndrome } \\
\left(\times 10^{-4}\right)(n)\end{array}$ & $\begin{array}{l}\text { Live births } \\
\text { (n) }\end{array}$ & $\begin{array}{l}\text { Live births } \\
\text { with Down's } \\
\text { syndrome (n) }\end{array}$ & $\begin{array}{l}\text { Prevalence of } \\
\text { live births with } \\
\text { Down's } \\
\text { syndrome } \\
\left(\times 10^{-4}\right)(n)\end{array}$ \\
\hline \multicolumn{8}{|c|}{ County Louth: } \\
\hline$<20$ & 6.2 & 502 & 0 & 0 & 994 & 2 & 20.1 \\
\hline $20-24$ & 6.7 & 3567 & 2 & 5.6 & 5090 & 3 & 5.9 \\
\hline $25-29$ & 8.8 & 4792 & 5 & 10.4 & 6327 & 4 & 6.3 \\
\hline $30-34$ & 13.8 & 3935 & 6 & 15.2 & 4165 & 6 & 14.4 \\
\hline $35-39$ & 39.3 & 2861 & 15 & 52.4 & 2163 & 12 & 55.5 \\
\hline $40-44$ & 138.2 & 1229 & 13 & 105.8 & 667 & 9 & 134.9 \\
\hline$\geqslant 45$ & 404.2 & 102 & 7 & 686.3 & 53 & 1 & 188.7 \\
\hline $\mathrm{N} / \mathrm{A}^{\star}$ & - & 24 & 0 & - & 30 & 0 & - \\
\hline \multicolumn{8}{|c|}{ Newry and Mourne District: $†$} \\
\hline$<20$ & 6.2 & 737 & 0 & 0 & 985 & 0 & 0 \\
\hline $20-24$ & 6.7 & 4052 & 0 & 0 & 4533 & 1 & 2.2 \\
\hline $25-29$ & 8.8 & 4926 & 4 & 8.1 & 5117 & 5 & 9.8 \\
\hline $30-34$ & 13.8 & 3905 & 6 & 15.4 & 3438 & 7 & 20.4 \\
\hline $35-39$ & 39.3 & 2454 & 11 & 44.8 & 1697 & 8 & 47.1 \\
\hline $40-44$ & 138.2 & 954 & 12 & 125.8 & 556 & 11 & 197.8 \\
\hline$\geqslant 45$ & 404.2 & 96 & 4 & 416.7 & 48 & 1 & 208.3 \\
\hline
\end{tabular}

*Maternal age at the birth not available.

† For 1961-73, the annual numbers of live births were estimated as described in the text.

also given. No significant differences between observed and expected numbers occurred for either all maternal ages or maternal ages under 30 years during $1961-70,1971-80$, or $1961-$ 80.

Inspection of maiden names and ages of mothers of children with Down's syndrome (details which were almost invariably available from records), who could have attended school during 1956-7, did not show any further former pupils of St Louis' School or St Vincent's School. Owing to the initial identification of an affected child of a mother who had attended the primary school in the vicinity of St Louis' School during 1956-7, the mothers of children with Down's syndrome born in County Louth or Newry and Mourne District were checked against the roll for this school. This showed a further two children with Down's syndrome born to mothers who were pupils at this primary school in 1956-7, although one of these mothers left the school in June 1956. Primary trisomy 21 was confirmed in all three children. Only one of the mothers was under 30 years of age at the birth of the affected child, and she was 28 years old. From the primary school roll, at least 250 girls would have attended the school in 1956-7. Assuming that the average number of live births per pupil, and the maternal age distribution of these births, are the same for the primary school girls as for girls attending the socioeconomically similar St Vincent's School in 1956-7, then the expected number of live births to these 250 former pupils is 720 , among which would be, on average, 1.4 babies affected with Down's syndrome. Among the estimated 370 live births to mothers under 30 years of age, 0.3 cases of Down's syndrome would be expected. Neither of these expected numbers differs significantly from the numbers observed.

\section{TURNER'S SYNDROME}

Further examination of the 159 questionnaires returned by former pupils of St Louis' School showed two live born offspring affected by chromosomal abnormalities other than Down's syndrome. In both, the anomaly was Turner's syndrome, characterised by monosomy X. Details are given in table 5. Turner's syndrome has a birth prevalence in females of 1 in 2000 to 1 in $5000,{ }^{14}$ which shows no apparent variation with parental age. ${ }^{15}$ Therefore, in the 203 live born girls of mothers who completed the questionnaire, at most 0.1 cases of Turner's syndrome would be expected. The two observed are a significant excess (nominal $\mathrm{p}<0.005)$. Cytogenetic analysis of peripheral blood lymphocytes previously sampled from one of the affected children (case A), carried out at the cytogenetics laboratory in Belfast, had shown a mosaic karyotype, 45,X/ $46, \mathrm{X}, \mathrm{i}(\mathrm{X})(\mathrm{q} 10)$. Samples of peripheral blood were obtained from both affected people and their parents for DNA analysis. Karyotyping of the other girl (case B) was also carried out, and showed non-mosaic 45,X. Analysis for six DNA polymorphic loci on the $\mathrm{X}$ chromosome indicated that the child with non-mosaic monosomy $\mathrm{X}$ was the result of maternal meiotic non-disjunction. The error resulting in the mosaic arose after fertilisation and involved the paternally derived $\mathrm{X}$ chromosome.

Table 5 Details of live births with Turner's syndrome to mothers who had attended St Louis' Secondary School, Dundalk, during 1956-7, as obtained from completed questionnaires

\begin{tabular}{llllllll}
\hline $\begin{array}{l}\text { Case } \\
\text { identifier }\end{array}$ & $\begin{array}{l}\text { Date of birth } \\
(\text { month/y })\end{array}$ & $\begin{array}{l}\text { Place of } \\
\text { birth }\end{array}$ & Parity & $\begin{array}{l}\text { Maternal } \\
\text { age }(y)\end{array}$ & $\begin{array}{l}\text { Paternal } \\
\text { age }(y)\end{array}$ & $\begin{array}{l}\text { Period at St Louis } \\
\text { Secondary School } \\
\text { (month/y) }\end{array}$ & Comment \\
\hline A & $5 / 68$ & Belfast & 1 & 24 & 29 & $9 / 57-6 / 62$ & Day girl \\
B & $1 / 70$ & Liverpool & 2 & 26 & 28 & $9 / 56-6 / 61$ & Boarder \\
\hline
\end{tabular}


Discussion

THE SCHOOLS

The high level of response $(89 \%)$ to the questionnaires issued to former pupils of $\mathrm{St}$ Louis' School, the publicity given to the original report ${ }^{1}$ of this cluster, and the absence of any further linkages of children with Down's syndrome to offspring of former pupils of the school, gives confidence in the completeness of the known number of births with Down's syndrome to women who had attended the school during 1956-7. If it is assumed that the additional 13 live births with an unknown maternal age (table 3 ) have the same maternal age distribution as those 374 live births with a known maternal age, and if it is further assumed that the same average number of live births with the same maternal age profile apply to those women who did not respond to the questionnaire as were found for those who did, then the maternal age adjusted expected number of cases of Down's syndrome among all live births to women who had attended St Louis' School during 1956-7 would increase to 0.80 . If no Down's syndrome occurred among the live born children of the non-responders, then an observed number of six compares with an expected number of 0.80 (nominal $\mathrm{p}<5 \times 10^{-4}$ ). If attention is concentrated on the 181 live births to mothers known to have been under 30 years of age when they gave birth, then, on the same assumptions about missing information, the expected number would be 0.18 (nominal $\left.\mathrm{p}<5 \times 10^{-6}\right)$. Therefore, given the high response rate and the relatively few live births for which information is lacking, the nominal significance of the excess is robust. Evidently, the cluster constitutes a highly unusual aggregation of Down's syndrome.

By contrast, the low response rate (48\%) among past pupils of St Vincent's School does not allow confidence in a comparison of observed and expected numbers. If it is assumed, however, that no further cases occurred among live births to non-responders and that these births have the same maternal age structure as those to responders, then the four births with Down's syndrome at all maternal ages, one of which was to a mother under 30 years old, would be very similar to the expected numbers for all past pupils of 3.7 and 0.8 , respectively. Given the absence of any further linkages between mothers of affected children and pupils of St Vincent's School during $1956-7$, it is reasonably clear that the marked excess of Down's syndrome among children of young mothers who were former pupils of St Louis' School does not extend to the offspring of past pupils of the larger St Vincent's School.

As well as the child with Down's syndrome born to a mother who had attended the primary school near St Louis' School in 1956-7, and who was originally ${ }^{1}$ (and mistakenly) thought to have attended St Louis' School, two affected offspring of past pupils of this primary school were identified. Questionnaires had not been issued systematically to past pupils of the primary school and so approximate expected numbers of cases of Down's syndrome in the offspring had to be derived. No significant differences between observed and expected numbers were found, although the comparisons could only be crude. However, the single affected birth to a mother under 30 years of age suggests that a notable excess of Down's syndrome is not present in the offspring of young mothers who had attended this primary school in 1956-7.

\section{COUNTY LOUTH AND NEWRY AND MOURNE} DISTRICT

The maternal age specific incidences of Down's syndrome for County Louth during 1961-70 and 1971-80 (shown in table 4), periods which include the dates of birth of the children with Down's syndrome born to mothers who had attended St Louis' School in 1956-7, do not indicate that the underlying risk of Down's syndrome, whether for all mothers or for young mothers specifically, is raised in comparison with that expected from reference rates. Our Lady of Lourdes' Hospital in Drogheda is the major maternity hospital in the north east of the Republic of Ireland. Between 1962 and 1973, 78 babies with Down's syndrome were born at this hospital out of a total of 27227 live births, giving a crude incidence of $28.6 / 10^{4}$ live births. This rate is comparable with the crude rate of 28.2/ $10^{4}$ live births found for County Louth during the similar period 1961-70. More than half of the mothers giving birth at Our Lady of Lourdes' Hospital during this period were not resident in County Louth, suggesting that the incidence of Down's syndrome in County Louth is typical of the north east of the Republic of Ireland as a whole.

Although routinely collated birth data do not exist for smaller geographical areas within County Louth, so that it is not possible to determine the prevalence of Down's syndrome among live births to mothers resident in Dundalk itself, a rough comparison of observed with expected numbers can be carried out from the numbers of women living in Dundalk and the rest of County Louth, which are available from census data. During 1961-70 and 197180 , just under one third of women of child bearing age resident in County Louth were living in the town of Dundalk. During these two periods, out of totals of 48 and 37 live births with Down's syndrome in the whole of County Louth, 13 and 14 affected births, respectively, were to mothers resident in Dundalk. Consequently, from this breakdown, there is no evidence of any unusual distribution of the risk of Down's syndrome between the town of Dundalk and the remainder of County Louth.

The observed prevalences for Down's syndrome among live births in the Newry and Mourne District of Northern Ireland during 1961-70 and 1971-80 are comparable with reference rates (table 4 ), and do not suggest an unusual level of risk. Certain assumptions had to be made to derive the maternal age distributions of live births in Newry and Mourne District, but these are unlikely to seriously underestimate the observed rates. 
Table 6 Maternal age specific incidences of Down's syndrome (per 104 live births) for various areas of Ireland (numbers of live births with Down's syndrome are given in parentheses)

\begin{tabular}{|c|c|c|c|c|c|c|}
\hline $\begin{array}{l}\text { Maternal } \\
\text { age group } \\
\text { (y) }\end{array}$ & Reference $^{13}$ & $\begin{array}{l}\text { County Louth } \\
\text { (1961-80) }\end{array}$ & $\begin{array}{l}\text { Newry and } \\
\text { Mourne } \\
\text { District } \\
(1961-80)\end{array}$ & $\begin{array}{l}\text { National Maternity } \\
\text { Hospital, Dublin }{ }^{16} \\
(1966-81)^{\star}\end{array}$ & $\begin{array}{l}\text { Counties Dublin, } \\
\text { Kildare, Wicklow, } \\
\text { and Galway } \\
(1981-90)\end{array}$ & $\begin{array}{l}\text { Northern Ireland } \\
(1974-97) t\end{array}$ \\
\hline$<20$ & 6.2 & $13.4(2)$ & $0 \quad(0)$ & 4 & $5.4(7)$ & $4.7(22)$ \\
\hline $20-24$ & 6.7 & $5.8(5)$ & $1.2(1)$ & 4 & $6.4(32)$ & $6.6(108.7)$ \\
\hline $25-29$ & 8.8 & $8.1(9)$ & $9.0(9)$ & 9 & $9.7(79)$ & $9.3(195.7)$ \\
\hline $30-34$ & 13.8 & $14.8(12)$ & $17.7(13)$ & 15 & $15.2(101)$ & $15.4(217.4)$ \\
\hline $35-39$ & 39.3 & $53.7(27)$ & $45.8(19)$ & 56 & $43.2(132)$ & $43.9(254.0)$ \\
\hline $40-44$ & 138.2 & $116.0(22)$ & $152.3(23)$ & & $137.8(93)$ & $153.2(191.6)$ \\
\hline$\geqslant 45$ & 404.2 & $516.1(8)$ & $347.2(5)$ & 166 & $390.2(16)$ & $322.0(21.2)$ \\
\hline
\end{tabular}

ॠThe number of Down's syndrome live births in each maternal age group is not given by O'Brien and Crowley, ${ }^{16}$ but overall there were 225 Down's syndrome babies among 111208 live births.

†Includes 956 live births and (with appropriate adjustment, see text) 74 cases of positive prenatal testing and subsequent induced abortion.

COMPARISON WITH OTHER AREAS IN IRELAND The live birth prevalences of Down's syndrome in County Louth and Newry and Mourne District may be compared with those that have been published for other areas of Ireland. O'Brien and Crowley ${ }^{16}$ examined the incidence of Down's syndrome among 111208 live births during 1966-81 at the National Maternity Hospital, Dublin. There were 225 babies with Down's syndrome live born in this hospital during this 16 year period. The maternal age specific incidences of Down's syndrome obtained by O'Brien and Crowley are shown in table 6. Johnson et $a l^{17}$ studied the prevalence of Down's syndrome among live births in 1981-90 in four Irish counties (Dublin, Kildare, Wicklow, and Galway) which were covered by registries participating in the European registration of congenital anomalies (EUROCAT) project. ${ }^{18}$ The maternal age specific rates are given in table 6 . The Lowry committee (on which NN sat) investigated the incidence of Down's syndrome in districts of Northern Ireland during 1974-84. ${ }^{11}$ The data presented were for live births and did not include cases of positive prenatal testing and subsequent induced abortion which is practised in Northern Ireland, unlike the Republic of Ireland. As induced abortions will influence the prevalence of Down's syndrome among live births, it is important to include data on induced abortions where these contribute a considerable fraction of the overall number of cases of Down's syndrome, to enable a proper comparison with areas where termination of pregnancy is not performed. One of us (NN) has collated relevant terminations in Northern Ireland during 1974-84. Also available from the EUROCAT registry for Northern Ireland (maintained by $\mathrm{NN}$ ) are the numbers of live births and induced abortions with Down's syndrome between 1985 and 1997. The number of terminations was multiplied by 0.74 before being added to the number of live births with Down's syndrome to account for the likelihood that the pregnancy would have resulted in a stillbirth. ${ }^{19}$ The resulting maternal age specific incidences for Northern Ireland for the period 1974-97 are given in table 6.

The rapidly rising risk of Down's syndrome with increasing maternal age is well established. Therefore, it is necessary to correct for the maternal age distribution of births when comparing areas where, or periods when, the proportion of births to older mothers differs, as is the case in Ireland. Under these circumstances, the comparison of crude incidences is likely to be misleading. It is clear, however, that when a comparison is made of maternal age specific rates of Down's syndrome for those areas of Ireland for which data are reasonably complete and reliable, then incidence of Down's syndrome does not show marked variations. The maternal age specific incidences for County Louth and Newry and Mourne District are compatible with those obtained from other areas of Ireland (table 6).

\section{INTERPRETATION OF CLUSTERS}

It seems clear that the excess occurrence of Down's syndrome among babies born to young mothers who were pupils of St Louis' School, Dundalk, in 1956-7 is highly unusual but that it does not extend generally to Dundalk or to the rest of County Louth, or to the adjacent Newry and Mourne District. Indeed, the maternal age specific incidences of Down's syndrome for County Louth and Newry and Mourne District are at the levels expected from reference rates and from other areas of Ireland. It must be considered, therefore, whether this localised cluster of cases associated with maternal attendance at St Louis' School during 1956 and 1957 represents a genuinely raised underlying risk of Down's syndrome, or whether the cluster is a rare effect of chance which does not reflect an increased risk. Although it would seem at face value that the play of chance would have to be extreme to account for this cluster, it must be appreciated that striking clusters will occur naturally as statistical fluctuations above a uniform underlying risk, and that the retrospective nature of most cluster investigations tends to enhance the nominal significance of clusters which are reported by alert clinicians.

Given the difficulty of distinguishing a causal signal from statistical noise, Rothman ${ }^{20}$ has argued that:

"with very few exceptions, there is little scientific or public health purpose to investigate individual disease clusters at all"

and this has been illustrated by Caldwell ${ }^{21}$ who noted that of 108 cancer clusters investigated by the United States Centers for Disease Control from 1961, no clear cause was found for any cluster. Olsen et $a l^{2}$ have highlighted the 
tendency in retrospective investigations of disease clusters for "boundary tightening" around the population in which the cluster is seen:

"the more narrowly the underlying population is defined, the less will be the number of expected cases, the greater will be the estimates of the excess rate, and often the more pronounced will be the statistical significance".

They have likened this process to the "Texas sharpshooter" who first fires his gun and then draws the target around the bullet hole, an analogy first used by Grufferman and Delzell ${ }^{23}$ when discussing clusters of Hodgkin's lymphoma. Glass et $a l^{4}$ illustrated this point with childhood leukaemia data for Los Angeles County. They noted that by severely tightening the boundaries around a few cases, they were able to create clusters comparable with those previously described in the scientific literature. They warned:

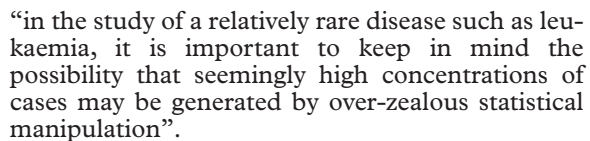

"in the study of a relatively rare disease such as leukaemia, it is important to keep in mind the possibility that seemingly high concentrations of cases may be generated by over-zealous statistical manipulation".

Boundary constriction is not just a problem of geographical area, but applies equally to the choice of time interval, age group, disease type, etc selected retrospectively. Recently, the problem of interpreting clusters has been emphasised by Hook and Carothers ${ }^{25}$ who analysed a reported excess of Down's syndrome in births to young mothers in Norway during 1985-6, and concluded that it was likely to have arisen by chance.

There is no doubt that the cluster of cases of Down's syndrome associated with St Louis' School is a retrospective observation which has had boundary tightening: the adverse health effect (Down's syndrome) and the location (maternal attendance at St Louis' School) were dictated by the initial report, and the cluster was further defined in retrospect by period $(1956-7)$ and age group (maternal age $<30$ years). This makes the true significance of this cluster difficult, if not impossible, to properly assess. Interpretation is further complicated by two of the five young mothers (cases 2 and 5) not attending the school at the same time, and by the error which led to Down's syndrome in the child of a further young mother (case 1) occurring after fertilisation. (That Down's syndrome in four of the six affected children originated at the first maternal meiotic division is not surprising as, in general, $80 \%-90 \%$ of cases are maternally derived, and of these, about $75 \%$ are due to first meiotic failure. ${ }^{26-27}$ ) This difficulty of interpretation is enhanced by the nominally significant excess of another chromosomal anomaly, Turner's syndrome, in the same group of children: one of the two was a mosaic, with the error after fertilisation involving the paternally derived $\mathrm{X}$ chromosome, and could not be due to any exposure of the mother as a child, but the second was the result of maternal meiotic non-disjunction and this is thought to occur in only $20 \%-30 \%$ of cases of Turner's syndrome. ${ }^{15}$
CAUSES OF DOWN'S SYNDROME

If the cluster of Down's syndrome is not a highly unusual chance fluctuation, but reflects a genuinely increased underlying risk, then what factor (or factors) might have caused this raised risk? It is apparent that the two possible causes originally suggested by Sheehan and Hillary, ${ }^{1}$ the influenza epidemic during the autumn of 1957 and radioactive contamination from the Windscale fire of October 1957, are implausible candidates. Of the five girls at St Louis' School during the years 1956-7 who later gave birth to a child with Down's syndrome while under 30 years of age, three (cases 2, 3, and 4) had left St Louis' School before the 1957 summer vacation, and these three in themselves constitute a significant excess over expectation (nominal $\mathrm{p}<0.001$ ), so that events occurring at the school in the autumn of 1957 cannot account for the excess. These three girls were not in Dundalk in the autumn of 1957 but were by then resident in either London or Dublin, so that factors local to Dundalk at this time could not have affected them. Furthermore, the influenza epidemic involved the whole of Ireland and it would also be expected that any radioactive contamination from the Windscale fire would influence a wider area than just St Louis' School, making these two occurrences improbable explanations for the highly localised nature of the cluster of Down's syndrome. Moreover, the testing of serum samples from six mothers of affected children for antibodies to several strains of influenza showed nothing unusual, ${ }^{1}$ and the radioactive plume from the Windscale fire travelled predominantly in a southeasterly direction over England to the mainland of Europe, rather than in a westerly direction over Ireland. ${ }^{28}$ It must also be noted that Down's syndrome in one of the affected children (case 1) whose mother was at the school in October 1957 has now been shown to be the result of an error in mitosis after fertilisation and it is difficult to envisage how this could have been influenced by childhood events.

The only well established risk factor for Down's syndrome is increasing maternal age, and there is still very little knowledge of the mechanisms that cause non-disjunction. Recently, it has been suggested that chromosome segregation is influenced by the extent and nature of the genetic recombination which occurs during the first meiotic division and that this influence can extend to the second meiotic division. ${ }^{29}$ However, the search for factors in the environment, or related to the health of the mother, which could affect segregation and hence result in increased meiotic nondisjunction has so far failed to identify anything conclusive. ${ }^{30}$ In the 1960 s it was found that thyroid disease was more common in women who had given birth to a child with Down's syndrome and this led to suggestions that increased concentrations of maternal thyroid antibodies could be associated with an increased risk. ${ }^{31}{ }^{32}$ Although several subsequent studies seemed to show increased concentrations of thyroid antibodies in mothers of children with Down's syndrome, these have 
been criticised for being conducted many years after the birth of the child and for the quality of the control data, and two recent studies have failed to confirm that the presence of thyroid antibodies in maternal serum samples is a significant risk factor. ${ }^{33} 34$

The finding that births of children with Down's syndrome seem to be aggregated led Pleydell ${ }^{35}$ to suggest the involvement of an infectious agent. Stoller and Collmann ${ }^{36}$ found a significant association between the occurrence of infectious hepatitis and the birth of children with Down's syndrome 9 months later, but other studies have found no evidence for such a correlation. ${ }^{37-39}$ A study ${ }^{39}$ of Down's syndrome in births in British Columbia, as well as finding no correlation with infectious hepatitis, found no variation in yearly or seasonal incidence nor any association with several other notifiable diseases (streptococcal infections, chicken pox, influenza, measles, mumps, poliomyelitis, and rubella). Nevertheless, seasonal variations have been reported (references cited by Puri and Singh $^{40}$ ) with most of these studies finding a lower frequency of affected births in the winter and a peak in the summer. However, a recent review by Stolwijk et $a l^{41}$ concluded that the prevalence of Down's syndrome is not affected by seasonality and this has been supported by analysis of data from the United Kingdom national Down's syndrome cytogenetic register. ${ }^{42}$ Kallen $^{43}$ has reviewed the conflicting data on maternal smoking and Down's syndrome, and after a study of Swedish health registries, has concluded that there is no direct risk from smoking on Down's syndrome. Suggestions that parity may influence the risk of Down's syndrome have not been supported by recent studies which have recognised that the confounding effects of different attitudes to termination of pregnancy may influence such findings. ${ }^{44}$ An increase in chromosomal anomalies has been found in children of mothers taking various drugs around the period of fertilisation. ${ }^{46}$ In a recent comprehensive study, Stoll et $a l^{47}$ examined a range of maternally related factors such as smoking, alcohol consumption, medication, diabetes, parity, and contraceptives, and also investigated paternal age, seasonality, and consanguinity. There was some suggestion that consanguinity and maternal diabetes might be associated with Down's syndrome, but no other factors were identified.

Perhaps the most extensively studied environmental factor in relation to Down's syndrome is ionising radiation. After a review of maternal preconception irradiation the United Nations Scientific Committee on the Effects of Atomic Radiation concluded that the data do not allow the dismissal of the possibility that radiation can cause an increase in maternal non-disjunction, but noted that this suggestion is not supported by data from the children of the Japanese atomic bomb survivors. ${ }^{48}$ The United States Committee on the Biological Effects of Ionizing Radiations, while recognising that non-disjunction is an important contributor to the spontaneous genetic burden in humans, concluded that low level irradiation may not be a serious concern. ${ }^{49}$ Data that sug- gest a higher incidence of Down's syndrome in areas of high background radiation have been severely criticised, ${ }^{48-50}$ and the earlier report of an increased incidence in the high background radiation area of Kerala $^{51}$ has not been supported by studies that used more reliable databases. ${ }^{52}$ Other studies have also failed to provide convincing evidence for Down's syndrome being produced by exposure to radiation, ${ }^{53-59}$ the one puzzling result being an apparently significant effect found for exposure to radiation in older fathers. ${ }^{60}$ Bound et $a l^{61}$ reported an association between the prevalence of Down's syndrome in births in northwest England during 1957-91 and the annual level of fallout from atmospheric nuclear weapons testing. However, in a preliminary study after the accident at Chernobyl in 1986, de Wals et $a l^{62}$ examined data submitted to EUROCAT registries and found no evidence for an increase in Down's syndrome associated with exposure around the time of conception, a finding recently confirmed by Dolk et al. ${ }^{63}$ In a review of national studies on the impact of the Chernobyl accident, Little ${ }^{64}$ noted that the increase in Down's syndrome in West Berlin in January 1987, first reported in English by Sperling et $a l,{ }^{65}$ is not confirmed in larger and more representative European series. Burkart et $a l^{66}$ have noted that the cluster in West Berlin was preceded by an equally significant cluster in northern Bavaria and a previously higher than average rate in southern Bavaria, both of which have their origins before the Chernobyl accident. An excess of cases in the Lothian Region of Scotland, reported as being associated with Chernobyl fallout, has not been confirmed in a recent more extensive analysis, ${ }^{68}$ and Stoll et al ${ }^{47}$ note that no space-time clusters were found in their study of the Strasbourg area, although the Chernobyl accident occurred during the course of the study. In a recent review, Verger ${ }^{69}$ concludes that the current evidence from epidemiological studies for an association between Down's syndrome and radiation is "contradictory and not convincing".

Any exposure that was to be responsible for the cluster of Down's syndrome associated with maternal attendance at St Louis' School would have to be highly localised in its effect to have such a pronounced influence solely upon the girls of this particular school, and seemingly would have to have occurred sometime between September 1955 and June 1957 when all of the women were pupils at the school for at least 1 academic year. It is possible that pupils experienced a very localised viral infection during this period, but there is no evidence to suggest this, and the presence of a considerable proportion of day girls makes this possibility less likely than when the school was thought to be a closed community. ${ }^{2}$ Discussions with teachers at St Louis' School did not show evidence of any other unusual exposures experienced predominantly by the girls of St Louis' School rather than by all girls resident in the general vicinity of Dundalk. 


\section{Conclusion}

In conclusion, we have been able to confirm a striking cluster of cases of Down's syndrome among births to young mothers who had attended St Louis' School in Dundalk at some time during 1956 and 1957. No excess risk of Down's syndrome was found for children of mothers who would have been resident elsewhere in Dundalk, or in the rest of County Louth, or in the adjacent area in the south of Northern Ireland, during this period. We have been unable to find a plausible common cause of the cases constituting this cluster, and details of the individual cases suggest that there may not be one. Previously proposed possible explanations, an influenza epidemic or the Windscale fire, both of which occurred in the autumn of 1957, can be effectively eliminated because they cannot account for the cluster, and their action would not be so localised. Owing to the retrospective nature of this investigation, and therefore, of the definition of the cluster by the cases observed, we are unable to rule out chance as being wholly or principally responsible, and this may well be the most reasonable explanation.

We acknowledge the pioneering work on this cluster carried out by Dr Patricia Sheehan, without which this study would not have been possible. We thank the many people who assisted us with this study, especially Mrs Aine Buckley and the families of children with Down's syndrome. We thank Sr Colmcille and S Maeve, St Louis' School; Sr Joan, St Vincent's School; Ms Analeen Quigley, Scoil Eoin Bàiske, Dundalk; Professor Irene Hillary, Mrs Carmel Byrne, Dr Andrew McDonald, Mr Dom Murtagh, Dr Rory O'Hanlon, Mr Kevin Marron, Ms Jackie Rooney, Ms Yvonne Gregory; Dr Zachary Johnson, EURORooney, Ms Yvonne Gregory; Dr Zachary Johnson, EUROCAT; Dr Victoria Coffey, Ms Bridie McCabe, the Foundation
for the Prevention of Childhood Handicap; the Down's for the Prevention of Childhood Handicap; the Down's Syndrome Association of Ireland; Professor Nollaig Parfrey, Dr Terry Brien, Cytogenetic Records, Dublin; Ms Audrey Arthur, St John of God's, Drumcar; Ms Evelyn Higgins, Health Centre,
Drogheda; Ms Rachel O'Donoghue, Births and Deaths Drogheda; Ms Rachel O'Donoghue, Births and Deaths
Register, Dublin; Mr Jerry Ruddy, Medically Handicapped Register, Dublin; Mr Jerry Ruddy, Medically Handicapped Register, Co Louth; Dr Carmel Mothersill, Dublin; Dr Rosaleen Corcoran, Director of Public Health, North-Eastern Health Board, and her staff. In Northern Ireland we thank Dr Nuala Keenan, Dr David Mayne, Mrs Dorothy Warnock, Tower Hill, Armagh; Miss Elizabeth Anderson and Ms Bronagh McCartan, Daisy Hill Hospital, Newry; Mrs Anne Cooney, S John of God's Hospital, Newry; Ms Christine Morgan, Mourne Hospital, Kilkeel; Ms Hilda McLaughlin for statistical analysis; Dr Chris Conliffe, Institute for Counselling and Personal Dewn's Syndrome Association of Northern Ireland; Dr Mina Hollinger, community paediatrician, and $\mathrm{Mr}$ Tom Smith, principal social worker, Newry; the doctors in medical practice in Newry and Mourne District; Dr Gilly Carson, Craigavon Hospital, Portadown. In Denmark we Gilly Carson, Craigavon Hospital, Portadown. In Denmark we thank Mrs Hanne Poulsen and Mrs Hanne Sand for expert technical assistance. We acknowledge the assistance of Dr Peter Gill and his staff at the Forensic Science Service, Birmingham, in the laboratory analysis of necropsy material from one of the cases with Down's syndrome. We are most grateful to Professors Sir Richard Doll, H John Evans, and Ernest B Hook for commenting on an early draft of this paper. This study was Republic of Ireland.

Sheehan PME, Hillary IB. An unusual cluster of babies with Down's syndrome born to former pupils of an Irish boardDown's syndrome born to former pup
ing school. $B M \mathcal{F} 1983 ; 287: 1428-9$.

2 Sheehan PME, Hillary IB. An unusual cluster of babies with Down's syndrome. BMF 1984;288:147.

3 Sharp PM, McConnell DJ. An unusual cluster of babies with Down's syndrome: was it caused by the Windscale fire? $B M F$ 1984;289:378

4 Brown A. Role of radiation in aetiology of Down's syndrome. BMF 1984;288:147-8.

5 Mikkelsen M, Poulsen H, Grinsted J, et al. Non-disjunction in trisomy 21: study of chromosomal heteromorphisms in 110 families. Ann Hum Genet 1980;44:17-28.

6 Saiki RK, Gelfand DH, Stoffel S, et al. Primer-directed enzymatic amplification of DNA with a thermostable DNA polymerase. Science 1988;239:487-91.

7 Petersen MB, Economou EP, Slaugenhaupt SA, et al. Linkage analysis of the human HMG14 gene on chromosome 21 using a GT dinucleotide repeat as polymorphic marker. 21 using a GT dinucleotide
8 Anon. Report and abstracts of the 5th International Workshop on Human Chromosome 21 Mapping 1994.
Tsukuba, Japan, November 9-11, 1994. Cytogenet Cell Tsukuba, Japan, Nove

9 Petersen MB, Schinzel AA, Binkert F, et al. Use of short sequence repeat DNA polymorphisms after PCR amplification to detect the parental origin of the additional chromosome 21 in Down syndrome. Am f Hum Genet 1991;48: 65-71.

10 Chakravarti A, Slaugenhaupt SA. Methods for studying recombination on chromosomes that undergo nondisjunction. Genomics 1987;1:35-42.

11 Antonarakis SE, Avramopoulos D, Blouin JL, et al. Mitotic errors in somatic cells cause trisomy 21 in about $4.5 \%$ of cases and are not associated with advanced maternal age. Nat Genet 1993;3:146-50.

12 Independent Committee (Chairman, Lowry S). Investigation into patterns of disease with possible association with radiation in Northern Ireland. Final report. Belfast: The Stationery Office, 1989.

13 Cuckle HS, Wald NJ, Thompson SG. Estimating a woman's risk of having a pregnancy associated with Down's syndrome using her age and serum $\alpha$-fetoprotein level. $\mathrm{Br} \mathcal{F}$ Obstet Gynaecol 1987;94:387-402.

14 Zinn AR. Growing interest in Turner syndrome. Nat Genet 1997;16:3-4.

15 Jacobs P, Dalton P, James R, et al. Turner syndrome: a cytogenetic and molecular study. Ann Hum Genet 1997;61:47183.

16 O'Brien N, Crowley P. Down's syndrome and maternal age. Ir Med F 1984;77:10-11

17 Johnson Z, Lillis D, Delany V, et al. The epidemiology of Down syndrome in four counties in Ireland 1981-90. $f$ Public Health Med 1996;18:78-86.

18 Lechat MF, Dolk H. Registries of congenital anomalies: EUROCAT. Environ Health Perspect 1993;101(suppl 2): 153-7.

19 Hook EB, Topol BB, Cross PK. The natural history of cytogenetically abnormal fetuses detected at midtrimester amneosentesis which are not terminated electively: new data and estimates of the excess and relative risk of late fetal death associated with $47,+21$ and some other abnormal karyotypes. Am f Hum Genet 1989;45:855-61.

20 Rothman KJ. A sobering start for the cluster busters' conference. Am F Epidemiol 1990;132:S6-13.

21 Caldwell, GG. Twenty two years of cancer cluster investigations at the Centers for Disease Control. Am f Epidemiol 1990;132:S43-7.

22 Olsen SF, Martuzzi M, Eliott P. Cluster analysis and disease mapping: why, when, and how? A step-by-step guide. BMF 1996;313:863-6.

23 Grufferman S, Delzell E. Epidemiology of Hodkgin's disease. Epidemiol Rev 1984;6:76-106.

24 Glass AG, Hill JA, Miller RW. Significance of leukemia clusters. F Pediatr 1968;73:101-7.

25 Hook EB, Carothers AD. Use of computer simulation to evaluate a putative cluster of genetic or teratologic outcomes: adjustment for "multiple hypotheses" and application to a reported excess of Down's syndrome. Genet Epidemiol 1997;14:133-45.

26 Yoon PW, Freeman SB, Sherman SL, et al. Advanced maternal age and the risk of Down syndrome characterized by the meiotic stage of the chromosomal error: a population-based study. Am f Hum Genet 1996;58:628-33.

27 Ballesta F, Queralt R, Gomez D, et al. Parental origin and meiotic stage of non-disjunction in 139 cases of trisomy 21. Ann Genet 1999;42:11-15.

28 Crick MJ, Linsley GS. An assessment of the radiological impact of the Windscale reactor fire, October 1957. Int $\mathcal{F}$ Radiat Biol 1984;46:479-506.

29 Lamb NE, Freeman SB, Savage-Austin A, et al. Susceptible chiasmate configurations of chromosome 21 predispose to non-disjunction in both maternal meiosis I and meiosis II Nat Genet 1996;14:400-5.

30 International Commission for Protection against Environmental Mutagens and Carcinogens. ICPEMC Meeting
Report No 3. Is the incidence of Down syndrome increasing? Mutat Res 1986;175:263-66.

31 Fialkow PJ, Hecht F, Uchida IA, et al. Increased frequency of thyroid autoantibodies in mothers of patients with Down's syndrome. Lancet 1965;ii:868-70.

32 Engel E. Autoantibodies and chromosomal aberrations. Lancet 1967; i:1271-2.

33 Torfs CP, van den Berg BJ, Oechsli FW, et al. Thyroid antibodies as a risk factor for Down syndrome and other trisomies. Am 7 Hum Genet 1990;47:727-34.

34 Gustafsson J, Anneren G, Ericsson UB, et al. Thyroid antibodies are not a risk factor for pregnancies with Down syndrome. Prenat Diagn 1995;15:451-4.

35 Pleydell MJ. Mongolism and other congenital abnormalities. An epidemiological study in Northamptonshire. Lancet 1957;i:1314-19.

36 Stoller A, Collmann RD. Area relationship between incidences of infectious hepatitis and of the births of children with Down's syndrome nine months later. 7 Ment Defic Res 1966;10:84-8.

37 Stark CR, Fraumeni JF. Viral hepatitis and Down's syndrome. Lancet 1966;i:1036-7.

38 Ceccarelli G, Torbidoni L. Viral hepatitis and Down's syndrome. Lancet 1967; i:438.

39 Miller JR, Baird PA. Some epidemiological aspects of Down's syndrome in British Columbia. Br f Prev Soc Med 1968;22:81-5. 
40 Puri BK, Singh I. Season of birth in Down's syndrome. $B r f$ Clin Pract 1995;49:129-30.

41 Stolwijk AM, Jongbloet PH, Zielhuis GA, et al. Seasonal variation in the prevalence of Down syndrome at birth: review. F Epidemiol Community Health 1997;51:350-3.

42 Morris JK, Alberman E, Mutton D. Is there evidence of clustering in Down syndrome? Int $\mathcal{F}$ Epidemiol 1998;27: 495-8.

43 Kallen K. Down's syndrome and maternal smoking in early pregnancy. Genet Epidemiol 1997;14:77-84

44 Kallen K. Parity and Down syndrome. Am f Med Genet 1997;70:196-201.

45 Chan A, McCaul KA, Keane RJ, et al. Effect of parity, gravidity, previous miscarriage, and age on risk of Down's syndrome: population based study BMF 1998;317:923-4.

46 Watanabe G. Environmental determinants of birth defects prevalence. Contr Epidem Biostatist 1979;1:91-100.

47 Stoll C, Alembik Y, Dott B, et al. Study of Down syndrome in 238942 consecutive births. Ann Genet 1998;41:44-51.

48 United Nations Scientific Committee on the Effects of Atomic Radiation. Sources and effects of ionizing radiation. Atomic Radiation. Sources and effects of ionizing radiation. UNSCEAR 1993 report to the General Assem

49 National Research Council. Health effects of exposure to low levels of ionizing radiation. BEIR V. Washington DC: levels of ionizing radiation. B

50 United Nations Scientific Committee on the Effects of Atomic Radiation. Sources and effects of ionizing radiation. 1977 report to the General Assembly, with annexes. New York: United Nations, 1977.

51 Kochupillai N, Veruma IC, Gerval MS, et al. Down's syndrome and related abnormalities in an area of high background radiation in coastal Kerala. Nature 1976;262. $60-1$.

52 Jaikrishan G, Andrews VJ, Thampi MV, et al. Genetic monitoring of the human population from high-level natural toring of the huf radiation areas of Kerala on the southwest coast of India. I. Prevalence of congenital malformations in newborns.

Sersol NA, al. A case-control study of congenital malformations and occupational exposure to low-level ionizing radiation. Am f Epidemiol 1988;127:22642.

54 Sever LE, Hessol NA, Gilbert ES, et al. The prevalence at birth of congenital malformations in communities near the Hanford site. Am F Epidemol 1988;127:243-54.
55 Knox EG, Lancashire RJ. Epidemiology of congenital malformations. London: The Stationery Office, 1991.

56 Francis, J, Snee, M. A case control study of trisomy 21 and maternal pre-conceptual radiography. Clin Radiol 1991;43: 343-6.

57 Shields LM, Weise WH, Skipper BJ, et al. Navajo birth outcomes in the Shiprock uranium mining area. Health Phys 1992;63:542-51.

58 Roman E, Doyle P, Ansell P, et al. Health of children born to medical radiographers. Occup Environ Med 1996;53:73-9.

59 Kallen B, Karlsson P, Lundell M, et al. Outcome of reproduction in women irradiated for skin hemangioma in infancy. Radiat Res 1998;149:202-8.

60 Strigini P, Pierluigi M, Forni GL, et al. Effect of X-rays on chromosome 21 nondisjunction. Am 7 Med Genet Suppl 1990;7:155-9.

61 Bound JP, Francis BJ, Harvey PW. Down's syndrome: prevalence and ionising radiation in an area of north west England 1957-91. F Epidemiol Community Health 1995;49: 164-70.

62 de Wals P, Bertrand F, de la Mata I, et al. Chromosome anomalies and Chernobyl. Int f Epidemiol 1988;17:230-1.

63 Dolk H, Nichols R, et al. Evaluation of the impact of Chernobyl on the prevalence of congenital anomalies in 16 regions of Europe. Int $\mathcal{F}$ Epidemiol 1999;28:941-8.

64 Little J. The Chernobyl accident, congenital anomalies and other reproductive outcomes. Paediatr Perinat Epidemiol 1993; 7:121-51.

65 Sperling K, Plez J, Wegner RD, et al. Frequency of trisomy 21 in Germany before and after the Chernobyl accident. Biomed Pharmacother 1991;45:255-62.

66 Burkart W, Grosche B, Schoetzau A. Down syndrome clusters in Germany after the Chernobyl accident. Radiat Res 1997; 147:321-8.

67 Ramsay CN. Ellis PM, Zealley H. Down's syndrome in the Lothian region of Scotland: 1978-89. Biomed Pharmacother 1991;45:267-72.

68 Huether CA, Haroldson K, Ellis PM, et al. Impact of prenatal diagnosis on revised live birth prevalence estimates of Down syndrome in the Lothian region of Scotland, 197892. Genet Epidemiol 1996;13:367-75.

69 Verger P. Down syndrome and ionizing radiation. Health Phys 1997;73:882-93.

\section{Correspondence and editorials}

Occupational and Environmental Medicine welcomes correspondence relating to any of the material appearing in the journal. Results from preliminary or small scale studies may also be published in the correspondence column if this seems appropriate. Letters should be not more than 500 words in length and contain a minimum of references. Tables and figures should be kept to an absolute minimum. Letters are accepted on the understanding that they be subject to editorial revision and shortening.

The journal also publishes editorials which are normally specially commissioned. The Editor welcomes suggestions regarding suitable topics; those wishing to submit an editorial, however, should do so only after discussion with the Editor. 


\section{CORRECTION}

Investigation of a cluster of children with Down Syndrome born to mothers who had attended a school in Dundalk, Ireland. G DEAN, N C NEVIN, M MIKKELSEN, G KARADIMA, M B PETERSEN, M KELLY, J O'SULLIVAN. 2000;57:793-804.

Three small typographical errors occurred in table 1 of this paper which gave details of the cases constituting the cluster.

For case number 3 the parity should be 2 and not 1 , and the maternal age should be 25 years and not 26 years.

For case number 5 the sex should be female $(\mathrm{F})$, not male $(\mathrm{M})$. These changes do not affect the remainder of the paper in anyway or the conclusions of the study.

\section{NOTICES}

International Short Course: Ventilation Design. 3-7 September 2001. Utrecht, The Netherlands

The course is organised by the Environmental and Occupational Health Group. Since May 2000 this group together with the Research Institute for Toxicology (RITOX) constitutes the Institute for Risk Assessment Sciences (IRAS). The actual move of the EOH group from Wageningen to Utrecht will take place during the summer of 2001 .

The course focuses on occupational hygienists, safety engineers, and all others who require more knowledge on the measures available for reducing worker exposure to air pollutants.

Course contents:

- General principles of airflow

- General ventilation

- Extraction ventilation

- Ductings and fittings

- Fans

- Ventilation measurement
- Practical ventilation measurement

- Air filtration and discharges to atmosphere

- Costs of ventilation.

For further information contact: Dr Mieke Lumens, Environmental and Occupational Health Group, Institute for Risk Assessment Sciences, Utrecht University, PO Box 80176, 3508 TD Utrecht, The Netherlands. Tel +31 317482080; fax +31 317485278; email M.Lumens@vet.uu.nl or visit our website http://www.slm.wau.nl/eoh/

\section{International Short Course: Biological} agents in the work and home environment: exposure assessment and health risk evaluation. 10-12 September 2001. Utrecht, The Netherlands.

The course is organised by the Division of Environmental and Occupational Health of the Institute for Risk Assessment Sciences, University of Utrecht (formerly the $\mathrm{EOH}$ group from Wageningen University).

The course focuses on occupational and environmental hygienists, physicians, and epidemiologists, and other researchers or practitioners in the field of exposure and health risk assessment.

Contents:

- Overview of most important biological agents: exposure to micro-organisms, their endotoxins and secreted toxins, specific bioallergens in various occupational environments and the home environment

- Sources and determinants of exposure to biological agents

- Recognition of exposure to biological agents

- Bioaerosol related health effects: infectious diseases, airway inflammatory diseases, organic dust toxic syndrome, allergy, cancer

- Epidemiology of health effects related to bioaerosols

- Microbiological and microscopic methods to evaluate exposure to microorganisms

- Immunoassays and biochemical assays to evaluate exposure to microorganisms (markers of exposure), and allergens

- Risk assessment and evaluation for biological agents

- Options to control exposure to microorganisms.
For further information contact: Dr Mieke Lumens, Environmental and Occupational Health Group, Institute for Risk Assessment Sciences, Utrecht University, PO Box 80176, 3508 TD Utrecht, The Netherlands. Tel +31 317482080; fax +31 317485278; email M.Lumens@vet.uu.nl or visit our website http://www.slm.wau.nl/eoh/

Work in the global village: an international high level conference on work life in the $21^{\text {st }}$ century. $15-17$ October 2001. Helsinki, Finland

The Conference is planned to be the first stage of a longer process, which will encourage discussion on work and globalisation at a worldwide level, and which will eventually lead to a high level follow up meeting. The objectives of the Conference are:

- To discuss the global values and ethics in occupational safety and health as a dimension of decent work

- To analyse the present status and perspectives of work life, and occupational safety and health in the process of globalisation

- To discuss the prerequisites for achieving occupational health and safety dimensions ensuring decent work for all working people

- To support the dissemination and implementation of the ILO safework programme and WHO global strategy on occupational health for all by preparing a draft declaration on occupational safety and health, and by producing a draft for a global strategy on the minimum level of occupational safety and health for all, and by drafting a strategy to improve intersectoral collaboration and cross cultural understanding

- To establish ad hoc workgroups to prepare discussion topics according to the themes of the safework programme for a follow up meeting.

Deadline for abstracts 15 April 2001; letters of approval 15 June 2001; deadline for early registration 15 August 2001.

Further information from: Work in the Global Village, Finnish Institute of Occupational Health, Taina Pääkkönen, Topeliuksenkatu 41 a A, FIN-00250 Helsinki, Finland. Tel 0035894747 2910; Fax 00358 92413 804; email taina.paakkonen@ occuphealth.fi www.occuphealth.fi/e/project/ globalwork/ 